\title{
Strekker arbeidstiden til for spesialistutdanning?
}

Den ukentlige arbeidstiden har vært stabil og moderat for norske sykehusleger de siste 20 årene.

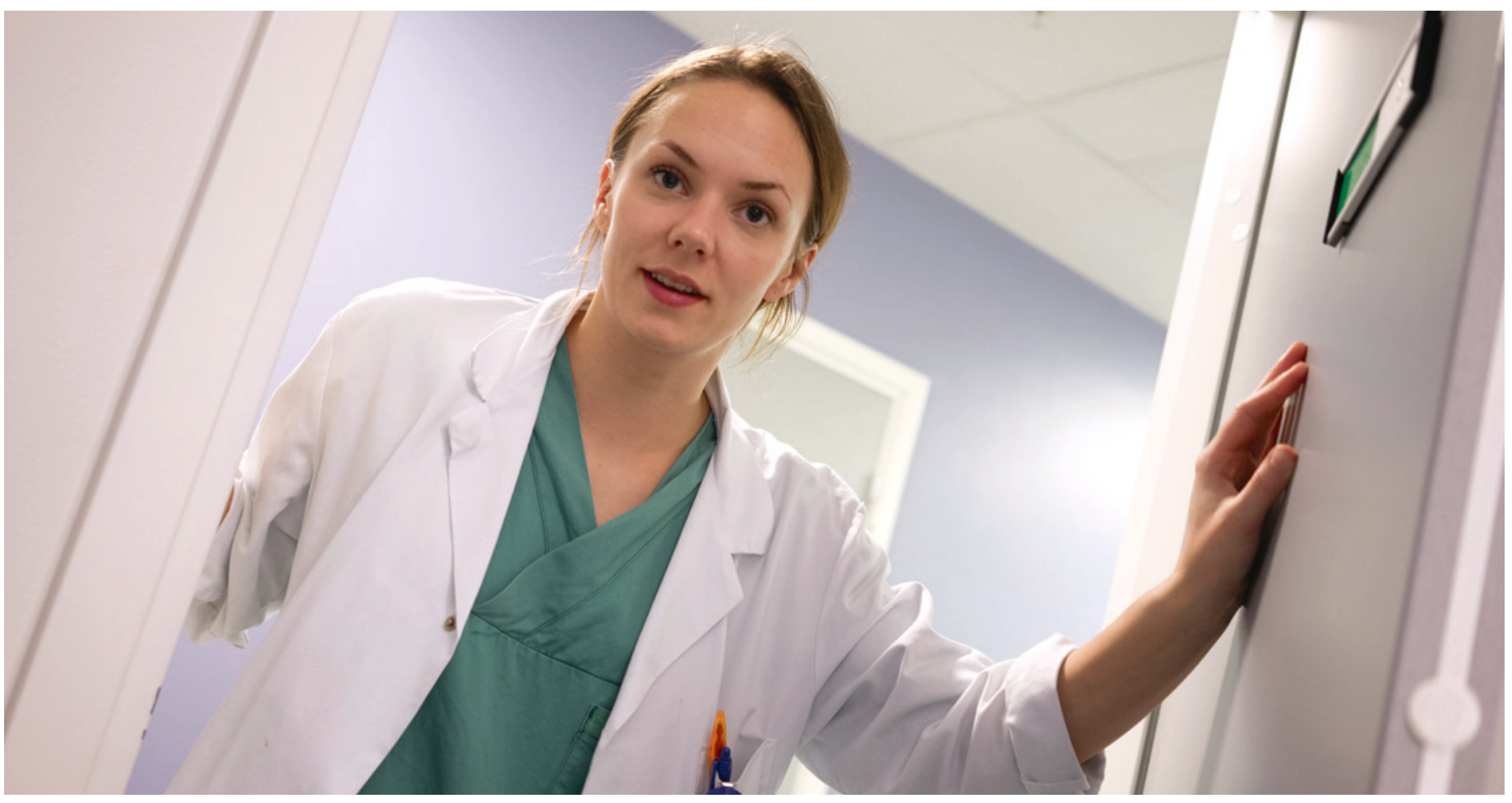

Sykehuslege ved St. Olavs hospital. Foto: Ole Kristian Losvik

I en fersk studie basert på Legeforskningsinstituttets referansepanel har vi sett på arbeidstidsutviklingen blant sykehuslegene i perioden 1994-2012. Sykehuslegenes vurdering av en 45 timers arbeidsuke i forhold til kvaliteten på spesialitetsutdanningen ble også kartlagt (1).

Studien viste at ukentlig arbeidstid har holdt seg stabil i den undersøkte perioden hos sykehusleger i fulltidsstillinger. For overleger var den 46-47 timer, og for leger i spesialisering 45-46 timer. I 2012 var andelen som jobbet mer enn 48 timer per uke, signifikant høyere blant overleger $(27-35 \%)$ enn for leger i spesialisering (11-20\%). Ukearbeidstiden var noenlunde lik for leger som i stor grad regulerer arbeidstiden selv, dvs. fastleger og privatpraktiserende spesialister, og for leger som i stor grad har regulert arbeidstid, dvs. leger med ansettelsesforhold i sykehus, forskning og administrasjon. Sammenliknet med sykehusleger fra andre europeiske land, rapporterte imidlertid norske sykehusleger kortere arbeidsuker. Nasjonale arbeidstidsbestemmelser, kulturelle verdier og økende antall leger kan trolig forklare den stabile og moderate ukearbeidstiden blant leger i Norge.

\section{Er 45 timer nok?}

I 2012 oppga et flertall av sykehuslegene (64\%) at 45 timers arbeidsuke er passe i forhold til å oppnå god nok kvalitet på spesialistutdanningen. Omtrent en tredel av sykehuslegene svarte at timeantallet kunne vært lavere $(25 \%)$ eller høyere $(11 \%)$. Det var signifikante forskjeller mellom aldersgrupper, stillingsgrupper og spesialiteter: Overleger, eldre leger og leger med kirurgiske spesialiteter mente at timetallet gjerne kunne vært høyere. Dette er i tråd med en rekke internasjonale studier, som viser at det er mest overleger og kirurger som oppgir at arbeidstidsforkortning for leger i spesialisering gjennom de siste ti årene har hatt negative konsekvenser for både spesialistutdanningens kvalitet og pasientbehandlingen.

Når flertallet av sykehuslegene i Norge opplever tilstrekkelig kvalitet på spesialistutdanningen med 45 timers arbeidsuke, støttes det i det europeiske arbeidstidsdirektivet som angir maksimalt 48 timers arbeidsuker for leger. Men forskjellene mellom spesialitetene indikerer et behov for større fleksibilitet i ukearbeidstid, særlig for kirurgiske spesialiteter.

\section{Judith Rosta \\ judith.rosta@legeforeningen.no}

Judith Rosta (f.1968) er seniorforsker ved Legeforskningsinstituttet.

Litteratur

. Rosta J, Aasland OG. Weekly working hours for Norwegian hospital doctors since 1994 with special attention to postgraduate training, work-home balance and the European Working Time Directive: a panel study. BMJ Open 2014; 4: e005704. 